\title{
IDENTIFICATION AND BIOLOGICAL ACTIVITY OF POTENTIAL PROBIOTIC BACTERIUM ISOLATED FROM THE STOMACH MUCUS OF BREAST-FED LAMB
}

\author{
H. Kiňová Sepová*, M. Dubničková, A. Bilková, M. Bukovský, L. Bezáková
}

Department of Cell and Molecular Biology of Drugs, Faculty of Pharmacy, Comenius University, Bratislava, Slovak Republic

Submitted: February 25, 2010; Approved: March 14, 2011.

\begin{abstract}
The lactic acid bacterium $\mathrm{E}$ isolated from the stomach mucus of breast-fed lamb was identified by sequencing of 16S rDNA fragment and species-specific PCR as Lactobacillus reuteri. Its potential antimicrobial activity and ability to modulate immune system in vitro and in vivo was determined. The growth inhibition of potential pathogens decreased from Staphylococcus aureus, Pseudomonas aeruginosa, Salmonella enterica ser. Minnesota to Escherichia coli. The lowest inhibition activity was observed in the case of Candida albicans. The ability of L. reuteri $\mathrm{E}$ to modulate biological activities of human and mouse mononuclear cells was estimated in vitro and in vivo, respectively. The production of IL-1 $\beta$ by monocytes in vitro was significantly induced by L. reuteri $\mathrm{E}$ (relative activity 2.47 ). The ability to modulate biological activities of mononuclear cells by living L. reuteri $\mathrm{E}$ cells in vitro in comparison to disintegrated L. reuteri $\mathrm{E}$ cells in vivo differed. For example lysozyme activity in vitro was inhibited while in vivo was stimulated (relative activities 0.30 and 1.83 , respectively). The peroxidase activity in vitro was stimulated while in vivo was inhibited (relative activities 1.53 and 0.17 , respectively). Obtained results indicate that L. reuteri $\mathrm{E}$ is potential candidate to be used in probiotic preparations for animals and/or human.
\end{abstract}

Key words: Lactobacillus reuteri - mononuclear cells - PCR - antagonistic activity - phagocytosis

\section{INTRODUCTION}

Lactobacillus spp. are the natural inhabitants of human and animal colon and vagina. Lactobacilli belong to the group of lactic acid bacteria that ferment saccharides to lactic acid. Specific strains of lactobacilli that are able to colonize body cavities seem to play an important role in maintaining a balanced microflora or preventing and lowering the incidence of recurrent urinary or digestive tract infections (18). Presence of Lactobacillus strains has positive effect on some digestive diseases, e.g. lactose intolerance, inflammatory bowel disease, constipation or post-antibiotic diarrhea (15).

Nowadays many researchers are looking for different probiotic bacteria that exhibit advantageous properties on human and/or animal health. These can be used in human or veterinary medicine in food supplements and/or probiotic preparations. According to FAO/WHO (5) guidelines, probiotic microorganisms must be exactly identified and characterize on strain level in several points: acid and bile salt resistance, ability to produce antimicrobial substances, adhere to mucus

*Corresponding Author. Mailing address: Department of Cell and Molecular Biology of Drugs, Faculty of Pharmacy, Comenius University, Kalinčiakova 8, 83232 Bratislava, Slovak Republic.; Tel.: +421 2 50117313.; E-mail: kinovasepova@ fpharm.uniba.sk 
and modulate immune system.

The aim of this study was to identify and characterize bacterial isolate $\mathrm{E}$ derived from the stomach mucus of breastfed lamb (Očová, Slovakia). According to microbiological and biochemical tests bacterium $\mathrm{E}$ showed several characteristics of lactic acid bacteria. For exact identification of isolate $\mathrm{E}$, sequencing of fragment of $16 \mathrm{~S}$ rDNA and PCR were used. To detect inhibition activity of isolate $\mathrm{E}$ against potential pathogens the streak line method on agar plates was performed. The ability of strain E to affect immune system of host was tested by in vitro and in vivo experiments.

\section{MATERIAL AND METHODS}

\section{Bacterial strains and growth conditions}

Bacterium E was isolated from the stomach mucus of three weeks old breast-fed lamb (Očová, Slovakia). As the reference strains for lactobacilli identification Lactobacillus reuteri CCM 3625 and L. acidophilus CCM 4833 (Czech Collection of Microorganisms, Brno, Czech Republic) were used. Lactobacilli were cultivated in de Man-Sharpe-Rogosa (MRS) broth (Oxoid, UK) $18 \mathrm{~h}$ in anaerobic conditions at $37^{\circ} \mathrm{C}$. Antagonistic activity of strain $\mathrm{E}$ was tested against potential pathogens: Staphylococcus aureus CNCTC Mau 29/58 (Czech National Collection of Type Cultures, Prague, Czech Republic), Pseudomonas aeruginosa CNCTC Ps 79/70, Escherichia coli ATCC 11229 (American Type Culture Collection, Manassas, Virginia, USA), Salmonella enterica ser. Minnesota SK 99/39 (Faculty of Pharmacy, Comenius University, Bratislava, Slovak Republic) and Candida albicans CCM 8180. Strains of potential pathogens were cultivated in peptone water (peptone $10.0 \mathrm{~g} / \mathrm{L}$; sodium chloride $5.0 \mathrm{~g} / \mathrm{L}$; disodium hydrogen phosphate dodecahydrate $9.0 \mathrm{~g} / \mathrm{L}$; potassium dihydrogenphosphate 1.5 $\mathrm{g} / \mathrm{L}$ ) for $18 \mathrm{~h}$ at $37^{\circ} \mathrm{C}$. For testing immunomodulatory activity E. coli ATCC 11229, Micrococcus luteus ATCC 4698, Enterococcus faecalis CCM 2122 and Candida albicans
CCM 8180 were used.

\section{Identification of lactobacilli}

Chromosomal DNA was isolated from $3 \mathrm{~mL}$ of an overnight culture of bacteria using DNA Easy ${ }^{\circledR}$ Tissue Kit (Qiagen, Germany), according to the manufacturer's protocol. For identification of new isolate $\mathrm{E}$ on the species level amplification of the part of $16 \mathrm{~S}$ rDNA by PCR and sequencing of PCR product were used. The PCR was performed according to Heilig et al. (10). Sequence analysis was performed at the Faculty of Natural Sciences (Comenius University, Bratislava, Slovakia). The nucleotide sequence was processed in computer software Vector NTI and compared with known sequences in GenBank (www.ncbi.nlm.nih.gov/BLAST). Species-specific PCR for $L$. reuteri was performed according to Kwon et al. (14).

\section{Electrophoresis of PCR products}

The PCR products $(8 \mu \mathrm{L})$ were separated in $1.5 \%$ agarose gel containing 1xTAE (18) in electric field of $80 \mathrm{~V}$. DNA was stained by "GoldView" (SBS Genetech Co. Ltd., China) and visualised under UV light $(\lambda=254 \mathrm{~nm})$.

\section{Antagonistic activity}

The turbidity of the broth cultures of strain E and potential pathogens was adjusted to equal that of 4 and 3 McFarland standard, respectively. $10 \mu \mathrm{L}$ of Lactobacillus culture were seeded in line to the middle of Petri dish containing MRS agar. Cultures were cultivated for $24 \mathrm{~h}$ in anaerobic conditions at $37^{\circ} \mathrm{C}$. After incubation, lactobacilli were killed by exposure to chloroform gases for $2 \mathrm{~h}$. Then the diluted cultures of potential pathogens were inoculated in volume $1 \mu \mathrm{L}$, in duplicate, perpendicular to the streak line of dead lactobacilli. Pathogens were incubated $24 \mathrm{~h}$ in aerobic conditions at $37^{\circ} \mathrm{C}$. After final incubation, zones of growth inhibition between lines of lactobacilli and pathogens were measured. Experiments were performed in twelve parallels. The degree of antagonistic 
activity was evaluated as following: $0-12 \mathrm{~mm}$ as low inhibition, $13-25 \mathrm{~mm}$ as intermediate inhibition and more than $25 \mathrm{~mm}$ as high inhibition according to Hütt et al. (12).

\section{Isolation of human mononuclear cells and their pre- incubation with strain $\mathbf{E}$}

The human mononuclear cells (MOs) from 6 healthy independent volunteers (OHT-Derer's Hospital, Bratislava, Slovakia) were isolated and purified by HistoPaque-1077 (Sigma, USA) according to Böyum et al. (2). MOs used were suspended in RPMI medium (diluted in saline 1:4) supplemented with $10 \%$ fetal bovine serum to concentration $2 \times 10^{6}$ cells $/ \mathrm{mL}$. In the next step, they were cultivated $18 \mathrm{~h}$ (at $37^{\circ} \mathrm{C}$ in $5 \% \mathrm{CO}_{2}$ atmosphere) exposed to $3 \times 10^{2} \mathrm{CFU} / \mathrm{mL}$ and $6 \times 10^{2} \mathrm{CFU} / \mathrm{mL}$ of strain E suspension according to Bukovský et al. (3). Control samples contained untreated human MOs.

\section{Administration of mouse model}

For the experiments male $\mathrm{C}_{57} \mathrm{BL}_{6}$ inbreeded mice (2527 g) (Velaz, Czech Republic) were used. Bacterial suspensions of strain $\mathrm{E}$ (the dose of strain $\mathrm{E}$ was $3 \times 10^{5} \mathrm{CFU} / \mathrm{kg}$ of mouse) were administered intraperitoneally to mice daily during 5 days period. To animals in control group physiological saline was applied. Mice were weighted before and after experiment. All experiments were performed in accordance with the Proclamation of the Government of Slovak Republic in July 9, 2003, Law $\mathrm{N}^{0} 289 / 2003$ in the Collection of Laws of the Slovak Republic, and in accordance to the local Ethical Committee of Faculty of Pharmacy (Comenius University, Bratislava, Slovakia). Mononuclear cells were isolated from mouse peritoneum using $5 \mathrm{~mL}$ of physiological saline.

\section{Phagocytic activity and index}

Phagocytic activity and index were determined microscopically. $100 \mu \mathrm{L}$ of $\mathrm{MOs}\left(2 \times 10^{6}\right.$ cells $\left./ \mathrm{mL}\right)$ were incubated $1 \mathrm{~h}$ at $37^{\circ} \mathrm{C}$ with $50 \mu \mathrm{L}$ of heat inactivated $E$. faecalis $\left(5 \times 10^{8}\right.$ cells $\left./ \mathrm{mL}\right)(3)$. The used ration strain/Wright's staining was performed according to the conventional methodology. Phagocytic activity was calculated as a percentage of the phagocyting mononuclear cells. Phagocytic index was determined as the average number of heat inactivated bacteria ingested per one active MO.

\section{Microbicidal and metabolic activities}

MOs, influenced in vivo and in vitro with strain $\mathrm{E}$, were ultrasonically disintegrated $(18 \mathrm{kHz}, 10 \mathrm{~s})$. The microbicidal activity of homogenate was tested on S. aureus, E. coli and C. albicans. $24 \mathrm{~h}$ cultures of S. aureus (grown on blood agar) and E. coli (grown on Endo agar) and $48 \mathrm{~h}$ culture of C. albicans (cultured on Sabouraud's agar) were washed twice in physiological saline and adjusted to $\mathrm{OD}_{540}=0.35$ (all culture media were purchased from Imuna, Slovakia). Bacterial suspensions were resuspended to $1 \times 10^{5}$ cells $/ \mathrm{mL}$. The turbidity of $C$. albicans was adjusted to $1 \times 10^{4}$ cells $/ \mathrm{mL}$. Microbial cultures in different amounts $(250 \mu \mathrm{L}$ of E. coli, $100 \mu \mathrm{L}$ of S. aureus, $100 \mu \mathrm{L}$ of C. albicans) were incubated with $100 \mu \mathrm{L}$ of crude homogenate of MOs. Incubation at $37^{\circ} \mathrm{C}$ lasted $1 \mathrm{~h}$. The number of surviving microbes was estimated after cultivation on appropriate media (bacteria $-24 \mathrm{~h}$ at $37^{\circ} \mathrm{C}$ on blood agar or Endo agar, yeast $48 \mathrm{~h}$ at $25^{\circ} \mathrm{C}$ on Sabouraud's agar). In control sample untreated MOs were used. Microbicidal activity was expressed as difference in number of $\mathrm{CFU} / \mathrm{mL}$ between control and test samples.

The ultrasonically disintegrated monocytes $(18 \mathrm{kHz}, 10 \mathrm{~s})$ were centrifuged $\left(2500 \mathrm{~g}, 10 \mathrm{~min}, 4^{\circ} \mathrm{C}\right)$. For lysozyme activity $150 \mu \mathrm{L}$ of supernatant were mixed with $50 \mu \mathrm{L}$ of the suspension of M. luteus $\left(\mathrm{OD}_{410}=0.8\right)$ in phosphate buffer $(\mathrm{pH}$ 6.2, $0.07 \mathrm{~mol} / \mathrm{L} \quad \mathrm{KH}_{2} \mathrm{PO}_{4}$ and $0.07 \mathrm{~mol} / \mathrm{L} \quad \mathrm{Na}_{2} \mathrm{HPO}_{4} .12 \mathrm{H}_{2} \mathrm{O}$ ). After $20 \mathrm{~min}$ absorbance at $410 \mathrm{~nm}$ was measured (MR 5000, Dynatech, USA). For the determination of peroxidase activity $50 \mu \mathrm{L}$ of the peroxidase substrate (benzene-1,2-diamine $0.5 \mathrm{mg} / \mathrm{mL}$, freshly diluted $\mathrm{H}_{2} \mathrm{O}_{2}-10 \mu \mathrm{L} / \mathrm{mL}$ and $0.1 \mathrm{M}$ sodium citrate tribasic dihydrate in distilled $\mathrm{H}_{2} \mathrm{O}, \mathrm{pH}$ 5.0) was 
added to $150 \mu \mathrm{L}$ monocyte supernatant. After incubation at $22^{\circ} \mathrm{C}$ for $20 \mathrm{~min}$ reaction was stopped with $\mathrm{H}_{2} \mathrm{SO}_{4}(50 \mu \mathrm{L}$, $4 \mathrm{~mol} / \mathrm{L}$ ) and absorbance was measured at $490 \mathrm{~nm}$ (MR 5000, Dynatech, USA).

In vitro experiments were performed on human monocytes and repeated at least 4 times. In vivo experiments were carried out in two groups of 6 mice.

\section{Influence on IL-1 $\beta$ production}

Ability of bacterium $E$ to induce production of IL-1 $\beta$ by phagocytes was determined spectrophotometrically $\left(\mathrm{A}_{450}\right.$; $\mathrm{MR}$ 5000, Dynatech, USA). $2 \times 10^{6}$ phagocytes per $\mathrm{mL}$ were cultivated with strain $\mathrm{E}\left(6 \times 10^{2} \mathrm{CFU} / \mathrm{mL}\right)$ in total volume $50 \mu \mathrm{L}$ in RPMI medium supplemented with $10 \%$ fetal bovine serum $18 \mathrm{~h}$ at $37^{\circ} \mathrm{C}$. Untreated monocytes were used as a control. The amount of IL-1 $\beta$ was determined by enzyme immunoassay method according to Immunotech's recommendations (Immunotech, France).

\section{Statistical analysis}

For calculations and statistical analysis OriginPro 7.5 was used. Data are expressed as mean values \pm standard deviations or as relative activities (the control sample was considered as
1.00). The statistical comparison between control and samples was performed by Student's t-test. The value $\mathrm{p} \leq 0.05$ was regarded as statistically significant.

\section{RESULTS}

\section{Identification of strain $\mathbf{E}$}

Several bacteria were isolated from the stomach mucus of breast-fed lamb. Isolate E showed attributes typical for genus Lactobacillus by microbiological and biochemical tests (Bukovský et al. - data unpublished). For unambiguous identification the partial nucleotide sequence of the 16S rDNA was used. Amplification of this gene was performed using primer set Bact-0011f and Lab-0677r (10). Nucleotide sequence of cca $700 \mathrm{bp}$ PCR product of strain E was used for the analysis of sequence similarity through BLAST (www.ncbi.nlm.nih.gov/BLAST). It showed a significant homology to the $16 \mathrm{~S}$ rDNA of known Lactobacillus spp. The highest homology (99\%) was achieved with strain L. reuteri LU3 (AY 735 406) (Figure 1). Identification of isolate $\mathrm{E}$ on species level was evaluated by species-specific PCR for $L$. reuteri according to Kwon et al. (14). Specific PCR product of $1100 \mathrm{bp}$ length was observed. Finally the new isolate was identified as $L$. reuteri and named $L$. reuteri $\mathrm{E}$.
E (1)

L. reuteri LU3 (6)

E (51)

L. reuteri LU3 (56)

E (101)

L. reuteri LU3

E (151)

L. reuteri LU3
ACGCCGGCGGTGTGCCTAATACATGCAAGTCGTACGCACTGGCCCAACTR ACGCCGGCGGTGTGCCTAATACATGCAAGTCGTACGCACTGGCCCAACT $\overline{\mathbf{G}}$ 56

ATTGATGGTGCTTGCACCTGATTGACGATGGATCACCAGTGAGTGGCGGA

ATTGATGGTGCTTGCACCTGATTGACGATGGATCACCAGTGAGTGGCGGA 106

CGGGTGAGTAACACGTAGGTAACCTGCCCCGGAGCGGGGGATAACATTTG (106) CGGGTGAGTAACACGTAGGTAACCTGCCCCGGAGCGGGGGATAACATTTG 156

GAAACAGATGCTAATACCGCATAACAACAAAAGCCRCATGGCTTTTGTTT (156) GAAACAGA TGCTAATACCGCATAACAACAAAAGCC舀ATGGCTTTTGTTT

Figure 1. Comparison of nucleotide sequences of $16 \mathrm{~S}$ rDNA fragment of L. reuteri $\mathrm{E}$ and L. reuteri LU3 (AY 735406, BLAST). Differences were found only in positions 55 and 191 . R - any of purines, A/G. 


\section{Antagonistic activity of $L$. reuteri $\mathrm{E}$}

Antagonistic activity of $L$. reuteri $\mathrm{E}$ was tested against several potential pathogens. The streak line method on agar plates with few modifications was used (12). The highest inhibition activity was detected against $S$. aureus; the inhibition zone was $25.75 \pm 4.90 \mathrm{~mm}$ from the line of lactobacilli. Other pathogens were inhibited weaker: P. aeruginosa (23.17 \pm $3.42 \mathrm{~mm})$, S. enterica ser. Minnesota (21.83 $\pm 3.47 \mathrm{~mm})$, E. coli $(20.75 \pm 2.58 \mathrm{~mm})$ and the lowest inhibition zone was observed in the case of $C$. albicans, $1.67 \pm 1.61 \mathrm{~mm}$ (Figure 2).

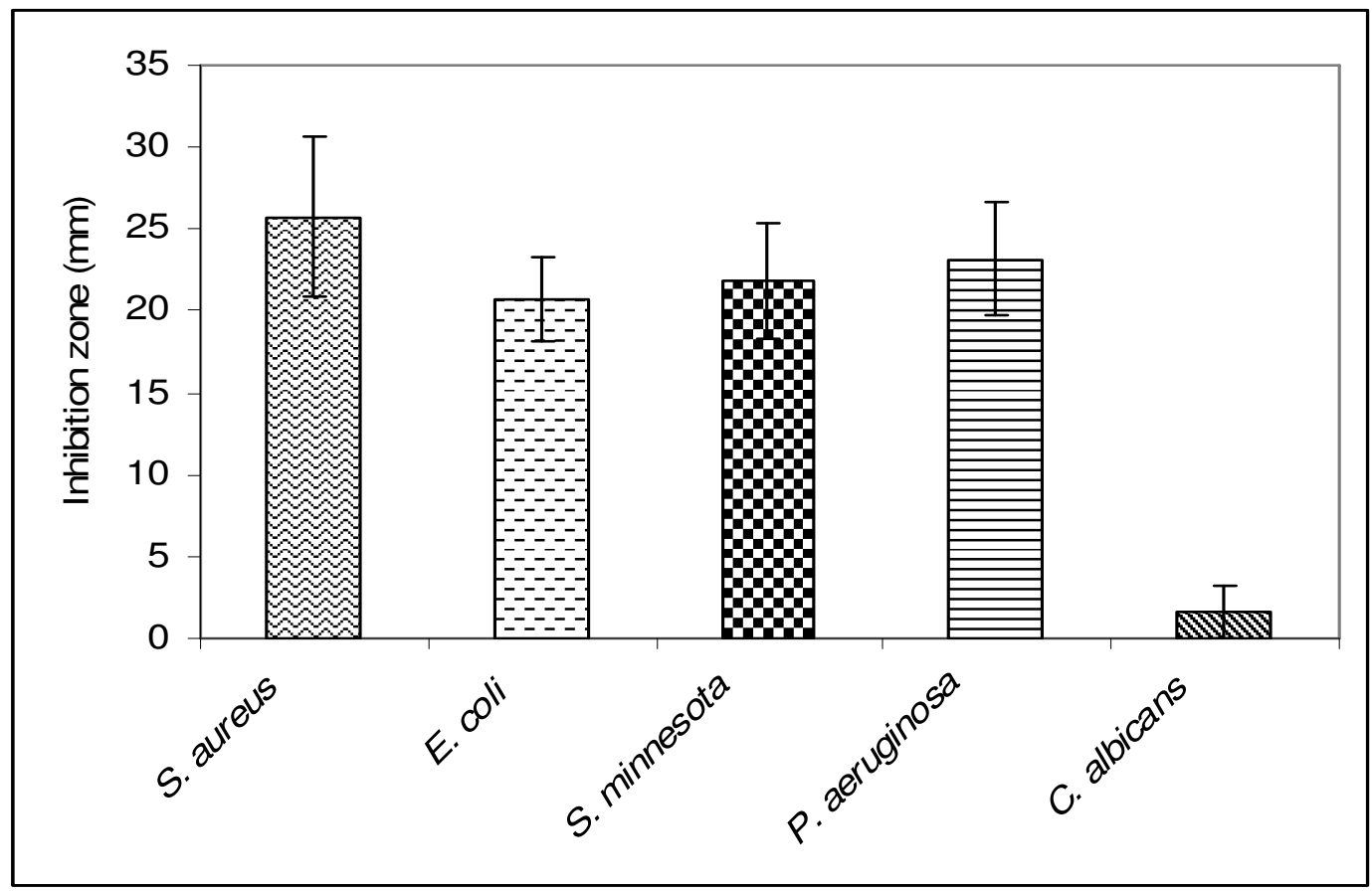

Figure 2. Antagonistic activity of L. reuteri E against selected potential pathogens.

Values are averages \pm SD from six parallels.

The effect of L. reuteri $\mathbf{E}$ on human mononuclear cells in vitro

MOs were incubated with L. reuteri E overnight. After incubation the number of MOs was not significantly changed, in comparison to control sample (Table 1). The ability of L. reuteri $\mathrm{E}$ to affect the phagocytic activity and index of phagocytosis was estimated. Significant increase of both phagocytic activity and index was observed. The relative phagocytic activity was 1.09 and relative phagocytic index was 1.36. Microbicidal activity was presented as a number of killed
CFU by MOs, that were pre-treated by L. reuteri $\mathrm{E}$. Microbicidal activities of MO cells treated with L. reuteri $\mathrm{E}$ against E. coli and C.albicans were decreased, relative activities were 0.72 and 0.42 , respectively. The lysozyme activity of induced MOs was significantly decreased (relative activity 0.30). Another protective metabolic activity of MOs against infection, peroxidase activity, was significantly stimulated by L. reuteri E (relative activity 1.53 ).

The phagocytes IL-1 $\beta$ production was significantly induced in vitro, relative activity was 2.47 (Table 1). 
Table 1. Effect of L. reuteri $\mathrm{E}$ on biological activities of MOs in vitro.

\begin{tabular}{|c|c|c|c|}
\hline In vitro experiment & Control sample, mean $\pm \mathrm{sd}$ & Treated sample, mean $\pm \mathrm{sd}$ & Relative activity \\
\hline $\begin{array}{l}\text { Number of surviving MOs after incubation } \\
\text { with } L \text {. reuteri } \mathrm{E}^{\text {a) }}\end{array}$ & $1.63 \pm 0.36 \times 10^{6} / \mathrm{mL}$ & $1.70 \pm 0.45 \times 10^{6} / \mathrm{mL}^{\mathrm{NS}}$ & 1.04 \\
\hline Phagocytic activity $^{\text {a) }}$ & $80 \pm 0.00 \%$ & $87 \pm 2.00 \%{ }^{* *}$ & 1.09 \\
\hline Phagocytic index ${ }^{\text {a) }}$ & $5.9 \pm 0.6$ & $8.0 \pm 0.1^{* *}$ & 1.36 \\
\hline The number of killed S. aureus ${ }^{\mathrm{a})}$ & $44 \pm 2 \times 10^{6} / \mathrm{mL}$ & $40 \pm 16 \times 10^{6} / \mathrm{mL}^{\mathrm{NS}}$ & 0.91 \\
\hline The number of killed $E$. coli $^{\mathrm{a})}$ & $146 \pm 16.4 \times 10^{6} / \mathrm{mL}$ & $105 \pm 6.8 \times 10^{6} / \mathrm{mL}^{*}$ & 0.72 \\
\hline The number of killed C. albicans ${ }^{\mathrm{a})}$ & $25 \pm 1.1 \times 10^{5} / \mathrm{mL}$ & $10 \pm 0.5 \times 10^{5} / \mathrm{mL}^{* * *}$ & 0.42 \\
\hline Lysozyme activity $^{\text {a) }}$ & $0.01 \pm 0.004$ & $0.003 \pm 0.000^{* *}$ & 0.30 \\
\hline Peroxidase activity ${ }^{\text {a) }}$ & $0.163 \pm 0.004$ & $0.250 \pm 0.036^{* * *}$ & 1.53 \\
\hline IL-1 $\beta^{\text {b) }}$ & $282.6 \pm 49.1 \mathrm{pg} / \mathrm{mL}$ & $698.2 \pm 213.5 \mathrm{pg} / \mathrm{mL}^{* *}$ & 2.47 \\
\hline
\end{tabular}

a) dose $0.5 \mathrm{mg}$ of dry weight of $L$. reuteri $\mathrm{E}$ per $\mathrm{mL} ;{ }^{\text {b) }}$ dose $1.0 \mathrm{mg}$ of dry weight of $L$. reuteri $\mathrm{E}$ per $\mathrm{mL}$. The number of phagocytes was $2 \times 10^{6} / \mathrm{mL}$ for each sample; experiments were done in 6 parallels. NS - non-significant sample, $\mathrm{p}-$ means statistically significant sample compared with control. $\mathrm{p}<0.001$ ( $* * *) ; \mathrm{p}$ $<0.01(* *) ; \mathrm{p}<0.05(*)$

\section{The effect of $L$. reuteri $\mathrm{E}$ on mouse macrophages in vivo}

L. reuteri $\mathrm{E}$ exhibited no lethal activity after 5 days of intraperitoneal application to mice. The average weight of mice in control group was not significantly changed after 5 days (from $24.8 \pm 0.9 \mathrm{~g}$ to $25.6 \pm 1.8 \mathrm{~g}$ ). The average weight of mice pretreated with $L$. reuteri $\mathrm{E}$ was significantly increased in comparison to control group (from $23.6 \pm 1.5 \mathrm{~g}$ to $27.4 \pm 0.1 \mathrm{~g}$ ). Isolated peritoneal mouse macrophages were tested for several biological activities (Table 2). Pre-treatment with L. reuteri $\mathrm{E}$ increased phagocytic activity and phagocytic index of mouse phagocytes. Relative phagocytic activity was 1.13 and relative phagocytic index was 1.51. Microbicidal activities of macrophages isolated from pre-treated mice were not influenced. The lysozyme activity of effected macrophages isolated from pre-treated mice was significantly increased (relative activity 1.83 ). Peroxidase activity was significantly inhibited (relative activity 0.17 ) (Table 2).

Table 2. The effect of L. reuteri E on biological activities of macrophages isolated from in vivo pretreated mice.

\begin{tabular}{|c|c|c|c|}
\hline In vivo experiment & Control sample, mean \pm sd & Treated sample, mean \pm sd & Relative activity \\
\hline $\begin{array}{l}\text { Number of surviving macrophages } \\
\text { after incubation with L. reuteri } \mathrm{E}\end{array}$ & $1.62 \pm 0.45 \times 10^{6} / \mathrm{mL}$ & $1.86 \pm 0.33 \times 10^{6} / \mathrm{mL}^{\mathrm{NS}}$ & 1.16 \\
\hline Phagocytic activity & $84 \pm 4 \%$ & $94 \pm 2 \% * *$ & 1.13 \\
\hline Phagocytic index & $7.33 \pm 2.45$ & $9.69 \pm 1.1^{* *}$ & 1.51 \\
\hline The number of killed $S$. aureus & $16 \pm 2 \times 10^{6} / \mathrm{mL}$ & $16 \pm 6 \times 10^{6} / \mathrm{mL}^{\mathrm{NS}}$ & 1.00 \\
\hline The number of killed $E$. coli & $59 \pm 11 \times 10^{6} / \mathrm{mL}$ & $66 \pm 13 \times 10^{6} / \mathrm{mL}^{\mathrm{NS}}$ & 1.17 \\
\hline The number of killed $C$. albicans & $60 \pm 18 \times 10^{5} / \mathrm{mL}$ & $50 \pm 12 \times 10^{5} / \mathrm{mL}^{\mathrm{NS}}$ & 0.86 \\
\hline Lysozyme activity & $0.03 \pm 0.004$ & $0.055 \pm 0.000^{* * *}$ & 1.83 \\
\hline Peroxidase activity & $0.404 \pm 0.018$ & $0.07 \pm 0.045^{* * *}$ & 0.17 \\
\hline
\end{tabular}

NS - non-significant sample, $\mathrm{p}$ - mans statistically significant sample in comparison with control. $\mathrm{p}<0.001$ (***); $\mathrm{p}<0.01$ (**). The number of macrophages was $2 \times 10^{6} / \mathrm{mL}$ for each sample, the number of mice in group was 6 for each sample. Dose of L. reuteri $\mathrm{E}$ was $25 \mathrm{mg} / \mathrm{kg}$. 


\section{DISCUSSION}

For identification of new isolate $\mathrm{E}$ derived from the stomach mucus of lamb the nucleotide sequencing was performed. $665 \mathrm{bp}$ nucleotide sequence of PCR product of isolate E showed highest homology (99\%) with the 16S rDNA of L. reuteri LU3 (AY 735 406). Two nucleotides in obtained sequence were identified ambiguously (any of purines, A or $\mathrm{G})$. In the reference sequence from GenBank there is $\mathrm{G}$ on both of these positions (Figure 1). Identification was confirmed by species-specific PCR (14), 1100 bp product was observed. This verifies the previous results, which recognized new isolate $\mathrm{E}$ as Lactobacillus reuteri.

The inhibition activity of L. reuteri $\mathrm{E}$ against potential pathogens decreased as follows: $S$. aureus $>$ P. aeruginosa $>$ S. enterica ser. Minnesota $>$ E. coli > C. albicans (Figure 2). According to Ocaña et al. (15) S. aureus growth is inhibited by Lactobacillus strains, which produce hydrogen peroxide. This might be one of the reasons of high growth inhibition of S. aureus by L. reuteri E. Production of bacteriocins should be another explanation of this effect. Bacteriocins, the antimicrobial proteinaceous substances, are generally defined as substances that kill related bacteria (4). Bacteriocins produced by Gram-positive $(\mathrm{G}+)$ bacteria are active mostly against other $\mathrm{G}+$ bacteria. Weaker inhibition activity of L. reuteri $\mathrm{E}$ was observed in the case of Gram-negatives (G-) than in S.aureus $(\mathrm{G}+)$. C. albicans that has diametrically different composition of cellular coating was inhibited the least.

Besides the exclusion of pathogens from the gut mucus lactobacilli can induce also host resistance to microbial pathogens by stimulation of non-specific immunity (6).

For evaluation of immunomodulatory potential of L. reuteri $\mathrm{E}$ in vitro and in vivo tests on mammalian cells were performed. The ability of induced MOs by L. reuteri $\mathrm{E}$ to phagocyte E. faecalis was comparable in both experiments (relative activity in vivo 1.13 and in vitro 1.09). Phagocytes release toxic agents, e.g., reactive oxygen intermediates and lytic enzymes, in various inflammatory reactions. Phagocytic activity results in the further recruitment of immunocompetent cells and the generation of inflammatory response. On the other hand microbicidal effect of MOs is limited to the production of cationic peptide molecules of different size and structure. During their interaction with bacteria they tend to find specific target in the bacterial cell membrane $(9,16)$. Modification of lipopolysaccharid (in G- bacterial membrane) or teichoic acid (in $\mathrm{G}+$ bacterial membrane) often makes bacteria resistant to microbicidal activity of mononuclear cells $(8,16)$. The difference in bactericidal activity of modulated phagocyting cells against E. coli and S. aureus can be explained by the different mechanism of action of MOs on G- and G+ bacteria. Microbicidal activity of pre-treated human MO cells against E. coli and C. albicans in vitro was inhibited (Table 1). The obtained results in the case of C. albicans are in good agreement with data obtained by streak line method.

Results of metabolic activities in vitro (human MO cells) and in vivo (mouse macrophages) showed the opposite course. Lysozyme activity in vitro was reduced, while in vivo increased. Vice versa, the peroxidase activity of MOs was increased in vitro while in vivo was decreased. Explanation of differences in peroxidase and lysozyme activities in vivo and in vitro could be in different administration of lactobacilli to mononuclear cells. In in vitro experiment live lactobacilli were used while in in vivo test lactobacilli were disintegrated before administration. Alive lactic acid bacteria can produce several extracellular substances e.g. organic acids, $\mathrm{H}_{2} \mathrm{O}_{2}$, bacteriocins etc. (1) which can affect metabolic activities of immunocompetent cells. Moreover organic acids produced by lactobacilli can reduce $\mathrm{pH}$ of environment (in our experiment phosphate buffer, $\mathrm{pH}$ 6.2) and simultaneously influence activity of lysozyme. Optimal pH for lysozyme activity is 6.2.

Anyway, there are also other agents and biochemical systems, except $\mathrm{H}_{2} \mathrm{O}_{2}$ production, which can play a role in the modulation of the immune system of mouse. 
Pro-inflammatory cytokines, including interleukin 1, play a pivotal, yet ambigous, role in inflammation. $L$. reuteri induced several proinflammatory and/or Th1 cytokines, such as IL-1, IL-2, and TNF, but not antiinflammatory or Th2 cytokines, such as IL-10. The authors are open to dispute, that outcome of probiotic treatment may depend on the immunologic state of the host and that changes in cytokine profile induced by probiotic strains may be site specific and dependent on the experimental system used (7).

Immunomodulating effects of probiotic bacteria may depend on the immunologic state of the host. It was further suggested that differences between specific strains of probiotic bacteria may exist. It was also observed that whole bacterial cells enhance immune cells proliferation and induce proinflammatory cytokines production, concretely tumor necrosis factor and interleukin 6 . In contrast probiotic bacteria mediate suppression of lymphocyte proliferation and $\mathrm{T}$ cells cytokine production (13).

Isolauri et al. (13) attempted to compare the antiproliferative effect of several probiotic bacterial strains in their nonviable forms. The suppressive effect of $10 \mu \mathrm{mol} / \mathrm{L}$ dexamethasone was compared with that of successful probiotics. Results indicated that some probiotic bacteria possess significant anti-inflammatory properties comparable to the therapeutic pharmaceutical agent. These findings further implicate the potential use of probiotic bacteria as immunomodulatory agents.

To estimate anti- or pro-inflammatory properties of L. reuteri $\mathrm{E}$, bacterial cells were tested for ability to affect IL$1 \beta$ production of phagocytes in vitro (Table 1 ). There are several studies investigating the usage of probiotic cells components for cytokine production. Lactobacilli, bifidobacteria and E. coli Nissle 1917 can affect pro- and antiinflammatory cytokines production in peripheral blood MOs (11).

Our results indicate that $L$. reuteri $\mathrm{E}$ isolated from the stomach mucus of lamb has auspicious probiotic properties, for example ability to inhibit the growth of several potential pathogens and modulate mammal's MOs activities in vitro as well as in vivo. Taken together, obtained data indicate that L. reuteri $\mathrm{E}$ is potential candidate for use in probiotic preparations for animals and/or human. However, additional experiments and testing are necessary.

\section{ACKNOWLEDGEMENTS}

This work was supported by grants of Slovak R\&D Assistance Agency (APVV/0354/07) and Ministry of Education SR (VEGA 1/4290/07).

\section{REFERENCES}

1. Annuk, H.; Shchepetova, J.; Kullisaar, T.; Songisepp, E.; Zilmer, M.; Mikelsaar, M. (2003): Characterization of intestinal lactobacilli as putative probiotic candidates. J. Appl. Microbiol. 94, p. 403-412.

2. Böyum, A. (1968): Isolation of leucocytes from human blood. Further observations. Methylcellulose dextran and ficoll as erythrocyte aggregating agents. Scand. J. Clin. Lab. Invest. Suppl. 97, p. 31-50.

3. Bukovský, M.; Mlynarčík, D.; Ondráčková, V. (1996). Immunomodulatory activity of amphiphilic antimicrobials on mouse macrophages. Int. J. Immunopharmacol. 18, p. 423-426.

4. Cleveland, J.; Montville, T.J.; Nes, I.F.; Chikindas, M.L. (2001). Bacteriocins: safe, natural antimicrobials for food preservation. Int. J. Food Microbiol. 71, p. 1-20.

5. FAO/WHO. 2002. Guidelines for the Evaluation of Probiotics in Food. Available at: ftp://ftp.fao.org/es/esn/food/wgreport2.pdf. Accessed 8 July 2010.

6. Foligne, B.; Nutten, S.; Grangette, C.; Dennin, V.; Goudercourt, D.; Poiret, S.; Dewulf, J.; Brassart, D.; Mercenier, A.; Pot, B. (2007). Correlation between in vivo and in vitro immunomodulation properties of lactic acid bacteria. World J. Gastroenterol. 13, p. 236-243.

7. Forsythe, P.; Inman, M. D.; Bienenstock, J. (2007). Oral treatment with live Lactobacillus reuteri inhibits the allergic airway response in mice. Am. J. Respir. Crit. Care Med. 175, p 561-569.

8. Gunn J.S. (2001). Bacterial modification of LPS and resistance to antimicrobial peptides. J. Endotox. Res. 7, p. 57-62.

9. Hancock, R.E.W.; Rozek, A. (2002). Role of membranes in the activities of antimicrobial cationic peptides. FEMS Microbiol. Lett. 206, p. 143149.

10. Heilig, H.G.H.J.; Zoetendal, E.G.; Vaughan, E.E.; Marteau, P.; 
Akkermans, A.D.L.; de Vos, W.M. (2002). Molecular diversity of Lactobacillus spp. and other lactic acid bacteria in the human intestine as determined by specific amplification of $16 \mathrm{~S}$ ribosomal DNA. Appl. Environ. Microbiol. 68, p. 114-123.

11. Helwig U.; Lammers K.M.; Rizzello F.; Brigidi P.; Rohleder V.; Caramelli E.; Gionchetti P.; Schrezenmeir J.; Foelsch U.R.; Schreiber S.; Campieri M. (2006). Lactobacilli, bifidobacteria and E. coli Nissle induce pro- and anti-inflammatory cytokines in peripheral blood mononuclear cells. World J. Gastroenterol. 12, p. 5978-5986.

12. Hütt, P.; Shchepetova, J.; Lōivukene, K.; Kullisaar, T.; Mikelsaar, M. (2006). Antagonistic activity of probiotic lactobacilli and bifidobacteria against entero- and uropathogens. J. Appl. Microbiol. 100, p. 1324-1332.

13. Isolauri E.; Sütas Y.; Kankaanpää P.; Arvilommi H.; Salminen S. (2001) Probiotics: effects on immunity, Am. J. Clin. Nutr. 73, p. 2001, 444-450.

14. Kwon, H.S.; Yang, E.H.; Yeon, S.W.; Kang, B.H.; Kim, T.Y. (2004). Rapid identification of probiotic Lactobacillus species by multiplex PCR using species - specific primers based on the region extending from $16 \mathrm{~S}$ rRNA through 23S rRNA. FEMS Microbiol. Lett. 239, p. 267-275.
15. Ocaña, V.S.; Pesce de Ruiz Holgado, A.A.; Nader-Macías, M.E. (1999). Growth inhibition of Staphylococcus aureus by $\mathrm{H}_{2} \mathrm{O}_{2}$-producing Lactobacillus paracasei subsp. paracasei isolated from human vagina. FEMS Immunol. Med. Microbiol. 23, p. 87-92.

16. Pesch A. (2002). How do bacteria resist human antimicrobial peptides? Trends Microbiol. 10, p. 179-185.

17. Tannock, G.W.; Tilsala-Timisjarvi, A.; Rodtong, S.; Ng, J.; Munro, K.; Alatossava, T. (1999). Identification of Lactobacillus isolates from the gastrointestinal tract, silage, and yoghurt by $16 \mathrm{~S}$ - 23S rRNA intergenic spacer region sequence comparisons. Appl. Environ. Microbiol. 65, p. 4264-4267.

18. Versalovic, J.; Koeuth, T.; Lupski, J.R. (1991). Distribution of repetitive DNA sequences in eubacteria and application to fingerprinting of bacterial genomes. Nucl. Acid Res. 19, p. 6823-6831.

19. Wilks, M.; Wiggins, R.; Whiley, A.; Hennessy, E.; Warwick, S.; Porter, H.; Corfield, A.; Millar, M. (2004). Identification and $\mathrm{H}_{2} \mathrm{O}_{2}$ production of vaginal lactobacilli from pregnant women at high risk of preterm birth and relation with outcome. J. Clin. Microbiol. 42, p. 713-717. 